\title{
INSIGHTS INTO GENDER, 'RURALITY’ AND THE LEGAL PRACTICE EXPERIENCE
}

\section{TRISH MUNDY*}

There has been a sustained focus over the past two decades on the status and position of women lawyers in the Australian legal profession. However, limited attention has been given to the particular experiences and retention of women lawyers in rural, regional and remote (RRR) legal practice. Feminist scholarship has highlighted the gendered way in which rural social space shapes understanding of identity and experience, suggesting the need to explore the ways in which the 'othering' of women in 'rural' space might bear on their legal practice experience. This article seeks to explore the intersection of gender and rurality in the context of RRR practice and the relevance of this intersection to the legal practice experience. It highlights some particular issues for women in RRR practice, considers ways in which gender is constructed in rural space and, through the case study examples of two female rural/regional lawyers, offers some experiential insights into the intersections of law, gender and 'rurality'.

\section{INTRODUCTION}

There has been a growing body of research and scholarship over the past two decades that has considered the profile, status and experience of women lawyers in the Australian legal profession. Broadly, this research concludes that women face significant systemic disadvantage within the profession, resulting in a clustering of women in entry level careers, ${ }^{1}$ work segmentation ${ }^{2}$

\footnotetext{
* Lecturer and PhD candidate, Griffith Law School, Griffith University, Gold Coast. The author thanks Dr Allan Ardill, Professor Paula Baron, Dr Lillian Corbin, Associate Professor Fiona Kumari-Campbell and Dr Kieran Tranter for their very helpful comments on an earlier draft of this paper.

${ }^{1}$ Law Society of New South Wales, After Ada: A New Precedent for Women in Law (29 October 2002), $5<\mathrm{http}: / /$ www.lawsociety.com.au/resources/Reports/papersandpresentations /026534>.

${ }^{2}$ Female lawyers are notably segmented within the profession both in terms of where they work and what they are doing. See Part II of this article for discussion of this point.
} 
and pay disparity ${ }^{3}$ as well as much higher levels of gender-based discrimination, ${ }^{4}$ all of which adversely impact on overall satisfaction levels and rates of retention. ${ }^{5}$

While there has been considerable focus on the ways in which women lawyers have been 'othered' ${ }^{\prime}$ in the profession generally, limited attention has been given to the particular experiences and retention of women lawyers in rural, regional and remote (RRR) practice and how the 'othering' of women in the context of 'rural' social space might bear on their practice experience and, ultimately, on their attraction and retention. Feminist and social geographical literature has highlighted the "powerful formative influence" that rurality has in terms of women's experience and understanding of their identity ${ }^{8}$ and the centrality of gender in rural community life. ${ }^{9}$ It has also noted the complex national, regional and localised constructions of rurality which invariably

\footnotetext{
${ }^{3}$ Urbis, 2010 Profile of the Solicitors of NSW (January 2011) Law Society of New South Wales $8<$ http://www.lawsociety.com.au/resources/surveysandstatistics/435772>; Law Society of New South Wales, above n 1, 8; Fiona McLeod SC and Leonie Kennedy, 'Women in Practice' in Patricia Easteal (ed), Women and the Law in Australia (LexisNexis, 2010) 350, 354; Terry Hutchinson and Heather Skousgaard, 'Women in the Queensland Legal Workplace: A Snapshot' (2008) 13 Deakin Law Review 37, 47.

${ }^{4}$ Law Society of New South Wales, above n 1, 14; Geraldine Neal, Unequal Partners? Women Solicitors' Experiences of Workplace Discrimination, Flexibility and Success in Queensland (PhD Thesis, Griffith University, 2009) 2 <www4.gu.edu.au:8080/adt-root/uploads/approved/ adt-QGU20100706.075946/public/02Whole.pdf>; Terry Hutchinson, 2003 Membership Survey: The Report (December 2006) Queensland Law Society, 33.

${ }^{5}$ Gabby Trifiletti, Taking up the Challenge: Women in the Legal Profession (Victorian Women Lawyers Association, 1999) 6; Neal, above n 4, 3.11; Law Society of New South Wales, above n $1,14$.

${ }^{6}$ Margaret Thornton, Dissonance and Distrust: Women in the Legal Profession (Oxford University Press, 1996) 19-20.

${ }^{7}$ Jo Little, 'Employment Marginality and Women's Self-Identity' in Paul Cloke and Jo Little (eds), Contested Countryside Cultures: Otherness, Marginalisation and Rurality (Routledge, 1997) $138,142$.

${ }^{8}$ Little, above n 7; Lisa Pruitt, 'Gender, Geography and Rural Justice' (2008) 23 Berkeley Journal of Gender Law and Justice 338, 372; Jo Little, 'Rural Geography: Rural Gender Identity and the Performance of Masculinity and Femininity in the Countryside (2002) 26 Progress in Human Geography 665.

${ }^{9}$ Margaret Alston 'Gender Perspectives in Australian Rural Community Life' in Chris Cocklin and Jacqui Dibden (eds), Sustainability and Change in Rural Australia (UNSW Press, 2005) $139,139$.
} 
shape our understanding of gender ${ }^{10}$ in both urban and rural spaces. ${ }^{11}$ This literature points to the need to explore the ways in which gender and rurality intersect in the context of RRR legal practice and the relevance of this intersection to the legal practice experience.

The article is structured into three parts: it begins by examining key research findings in relation to women lawyers in the Australian legal profession, highlighting some particular issues for women in RRR practice. It then explores a number of perspectives on the intersection of gender and rurality to consider ways in which gender is constructed in rural space, including the role of 'rural masculinities'. Finally, it considers the case study examples of two female rural/regional lawyers ${ }^{12}$ from these theoretical perspectives and offers some experiential insights into the intersections of law, gender and 'rurality'. The article concludes that, while RRR practice offers an enriching and rewarding experience in many respects, the nature of gendered arrangements in some rural sites may mean that women lawyers face particular challenges, including those of managing increased levels of visibility in rural space, more pronounced feelings of professional isolation, as well as the effects of a more conservative and traditional gender regime. It argues for a greater research focus on the gendered experience of law in RRR practice, which to date has been largely absent.

\section{Women Lawyers in Australian Legal Practice}

The contemporary picture of Australian legal practice for women lawyers has been well documented over the past two decades. In her seminal work, Dissonance and Distrust ${ }^{13}$ Margaret Thornton illustrated how women have been constructed as 'other' to the male in the legal profession and relegated to

\footnotetext{
${ }^{10}$ Paul Cloke and Paul Milbourne, 'Deprivation and Lifestyles in Rural Wales II - Rurality and the Cultural Dimension (1992) 8 Journal of Rural Studies 359, 361; Andrew Gorman-Murray, Kate Darian-Smith and Chris Gibson, 'Scaling the Rural: Reflections on Rural Cultural Studies' (2008) 45 Australian Humanities Review $37<\mathrm{http} / / /$ epress.anu.edu.au/ahr/ 045/pdf/essay03.pdf $>$.

${ }^{11}$ Barbara Pini, Masculinities and Management in Agricultural Organisations Worldwide (Ashgate, 2008) 18.

12 These case study interviews were conducted as part of the early phases of a broader phenomenological research study into the lived experience of male and female lawyers in RRR areas. These preliminary interviews were designed to assist with the identification of research questions and the development of appropriate methodological approaches. Both interviews were conducted in the interviewee's current place of work, were audio-taped, transcribed and analysed following the interviews.

${ }^{13}$ Thornton, above $\mathrm{n} 6$.
} 
the position of 'fringe-dwellers' almost a century after being 'let in' to the legal profession. ${ }^{14}$ She highlighted the ways in which masculinity has been constructed 'positively and normatively in terms of legal culture, reason and rationality' while the feminine has been linked to 'nature, the body, disorder and irrationality'. ${ }^{15}$ This has taken place, for example, through the many gendered assumptions about carer and child care obligations. The woman is positioned 'in relation to her fertility and the gendered assumptions that flow from this' ${ }^{16}$ For example, the woman is assigned to caring roles reflected in the sexual division of labour. It is expected that women should take on roles that are 'derivative of caring, ${ }^{17}$ 'behind the scenes' or 'handmaiden' roles. ${ }^{18}$

Since Thornton's work, there have been at least 23 reports or studies that have been conducted across Australia in relation to the status and position of women in the Australian legal profession. ${ }^{19}$ When they are taken together, it is clear that these continue to find that little has changed for women in the Australian legal profession and that their career patterns are 'remarkably similar' across Australian jurisdictions. ${ }^{20}$ There is 'a range of exclusionary workplace practices that operate to hold women back from career progression as well as gender stereotyping, role traps and otherness that have historically underpinned the profession of law'. ${ }^{21}$ Grouped into two themes 'segmentation' and 'discrimination' — some of the key types of

\footnotetext{
${ }^{14}$ Ibid 152.

15 Ibid 1.

${ }^{16}$ Ibid 144 .

${ }^{17}$ Ibid 24.

${ }^{18}$ Ibid 149.

${ }^{19}$ See Trifilleti, above n 5, 23, for a comprehensive bibliography of reports and studies up until 1999 when the report was published. Since 1999 major reports have included: Victorian Women Lawyers, A Snapshot of Employment Practices 2001 - A Survey of Victorian Law Firms (November 2001) <http://www.vwl.asn.au/downloads/EmploymentPractices2001.pdf>; Law Society of New South Wales, After Ada, above n 1, 5; Sue Kaufmann and Georgina Frost, Flexible Partnership - Making it Work in Law Firms (December 2001) Victorian Women Lawyers <http://www.vwl.asn.au/downloads/vwl_flexible.pdf>; Victorian Women Lawyers, A $360^{\circ}$ Review: Flexible Work Practices - Confronting Myths and Realties in the Legal Profession (11 November 2005) <http://www.vwl.asn.au/downloads/ VWL\%20360DegreeReport.pdf>; Law Institute of Victoria and Victorian Women Lawyers, Bendable or Expendable? Practices and Attitudes Towards Work Flexibility in Victoria's Biggest Legal Employers (July 2006) <http://www.vwl.asn.au/downloads/ Bendable_or_Expendable.pdf $\mathrm{s}$; Terry Hutchinson and Heather Skousgaard, 'Women in the Queensland Legal Workplace: A Snapshot' (2008) 13 Deakin Law Review 37; Neal, above n 4 .

${ }^{20}$ Trifiletti, above n 5,19 .

${ }^{21}$ Neal, above n 4, 1.24.
} 
discrimination are discussed below and the discussion is augmented with literature relating to female lawyers in RRR areas, where this is available.

\section{A Segmentation}

Females now comprise more than 50 per cent of all law school graduates ${ }^{22}$ and, while the numbers of female solicitors entering the profession has consequently increased, demographic data suggest that significant numbers are choosing not to go on to practise law. Those who do will generally practise for a shorter period of time than men, ${ }^{23}$ many leaving the profession within 5 years of entry. ${ }^{24}$

Female lawyers are notably segmented within the profession, both in terms of where they work and what they are doing. There continues to be a move away from the private sector by female lawyers. Proportionally, they are more likely to be found in the government, community and corporate sectors. ${ }^{25}$ While there are no national data available, NSW data published by the Law Society of New South Wales in its Annual Profile of the Solicitors of NSW show that, in the NSW practising profession, there is roughly a 60:40 per cent split in the private sector participation of male and female solicitors respectively, while their overall presence in the profession is 54.1 per cent (male) and 45.9 per cent (female). ${ }^{26}$ In addition, women currently represent more than 63 per cent of all NSW government lawyers ${ }^{27}$ and, nationally, as much as 80 per cent of community legal centre staff. ${ }^{28}$ It appears that this trend away from the private sector may be more pronounced in RRR areas, with data showing that the gender distribution within the NSW RRR private

\footnotetext{
${ }^{22}$ Women make up 54.37 per cent of all law graduates from Queensland law schools. There were more women than men in four of the five law schools (except Bond University): See Sue Purdon and Aladin Rahemtula (eds), A Women's Place - 100 Years of Queensland Women Lawyers (Supreme Court of Qld Library, 2005) 769, cited in Neal, above n 4, 1.5. For additional comment in relation to female law graduates see McLeod and Kennedy, above n 3, 350 .

${ }^{23}$ Law Society of New South Wales, above n 1, 15; Hutchison and Skousgaard, above n 3, 40, 46; Trifiletti, above n 5, 8-9; Rosemary Hunter, 'Border Protection in Law's Empire: Feminist Explorations of Access to Justice' (2002) 11(2) Griffith Law Review 263, 279.

${ }^{24}$ McLeod and Kennedy, above n 3, 350.

${ }^{25}$ Urbis, above n 3, 16; Trifiletti, above n 5, 19.

${ }^{26}$ Urbis, above $\mathrm{n} 3$, i.

${ }^{27}$ Ibid 16.

${ }^{28}$ Legal Aid Commission of New South Wales, Final Report - Review of the NSW Community Legal Centres Funding Program (February 2006), 33 <www.clcnsw.org.au/public_resource_ details.php?resource_id $=40>$.
} 
sector is approximately 65 per cent (1642) and 35 per cent (881) male and female solicitors respectively. ${ }^{29}$

The above figures are summarised in the following table and show a comparison to levels of female and male participation in the NSW profession overall:

\begin{tabular}{|l|c|c|c|c|}
\hline & $\begin{array}{c}\text { \% Female } \\
\text { Solicitors in } \\
\text { profession }\end{array}$ & $\begin{array}{c}\% \text { Female } \\
\text { Solicitors } \\
\text { (RRR) }\end{array}$ & $\begin{array}{c}\text { \% Male } \\
\text { Solicitors in } \\
\text { profession }\end{array}$ & $\begin{array}{c}\% \text { Male } \\
\text { Solicitors } \\
\text { (RRR) }\end{array}$ \\
\hline Private sector & $41.1 \%$ & $34.9 \%$ & $58.9 \%$ & $65.08 \%$ \\
\hline Government & $63.2 \%$ & $64 \%$ & $36.8 \%$ & $36 \%$ \\
\hline Corporate & $53.5 \%$ & $52.3 \%$ & $46.5 \%$ & $47.7 \%$ \\
\hline Total & $45.9 \%$ & $38.5 \%$ & $54.1 \%$ & $61.5 \%$ \\
\hline
\end{tabular}

The NSW data are consistent with trends in other Australian jurisdictions. In Queensland, the current distribution of male and female solicitors in RRR areas is not ascertainable from QLS published data. However, other research reporting on QLS data for the year 2005 has noted that 71 per cent of female solicitors were practising in Brisbane and its suburbs, while only 29 per cent were practising in regional/rural areas. Conversely, 61.8 per cent of male solicitors were located in Brisbane and its suburbs and 38.2 per cent were in regional/rural practice. ${ }^{30}$ The proportion of female rural practitioners in Victoria has in the past been estimated to be around 22 per cent. ${ }^{31}$

The progression of women in the profession has been disappointingly slow, particularly given the ongoing efforts of organisations such as women lawyers' associations to promote the status and position of women within the profession. In all Australian jurisdictions women continue to be significantly under-represented in positions of partnership and as sole practitioners. For example, of the female solicitors found in NSW private practice in 2010, 9.1 per cent were partners, 13.7 per cent sole practitioners and 77.2 per cent

\footnotetext{
${ }^{29}$ My thanks to the Law Society of NSW for providing this data in relation to gender distribution in regional, rural and remote (RRR) areas of NSW as at 1 July 2010.

${ }^{30}$ Neal, above $n$ 4, 3.10.

${ }^{31}$ Melinda Brown, 'A Country Practice' (2000) 74(9) Law Institute Journal 14, 18.
} 
were employees. ${ }^{32}$ The figures for the NSW profession as a whole are 18.6 per cent (partners), 24.3 per cent (sole practitioners) and 57.1 per cent (employees). ${ }^{33}$ There is evidence that the RRR sector may be somewhat more favourable than the legal sector as a whole. For example, in NSW, the figures for RRR areas are 9.4 per cent, 20.3 per cent and 69.1 per cent respectively, suggesting that more female practitioners in RRR areas can be found in sole practice than their city and metropolitan counterparts. ${ }^{34}$ The above figures are represented in the following table:

\begin{tabular}{|l|c|c|c|}
\hline & $\begin{array}{c}\text { \% NSW } \\
\text { Profession as a } \\
\text { whole }\end{array}$ & $\begin{array}{c}\text { \% Females in } \\
\text { profession as a } \\
\text { whole }\end{array}$ & $\begin{array}{c}\text { \% Female } \\
\text { Solicitors (RRR) }\end{array}$ \\
\hline Partner & $18.6 \%$ & $9.1 \%$ & $9.4 \%$ \\
\hline $\begin{array}{l}\text { Sole } \\
\text { Practitioner }\end{array}$ & $24.3 \%$ & $13.7 \%$ & $20.3 \%$ \\
\hline Employee & $57.1 \%$ & $77.2 \%$ & $69.1 \%$ \\
\hline
\end{tabular}

It follows, then, given the low rates of partnership participation and sole practitioner status, that women are predominately engaged as employed solicitors. They also tend to be concentrated in the younger age brackets of the profession and a significant majority has been admitted only in the last 10 years. ${ }^{35}$ After the age of 30 , the proportion of women in practice tends to decrease ${ }^{36}$ reflecting exit at child bearing age and higher rates of attrition generally. Research has shown that, in terms of overall career satisfaction, the most satisfied are women in partnership while the least satisfied are female employees ${ }^{37}$ suggesting high levels of dissatisfaction within the ranks of female lawyers. Studies also indicate that women are more likely to be located in larger firms (and male solicitors in smaller firms) ${ }^{38}$ and are more likely to work in family law. ${ }^{39}$

\footnotetext{
${ }^{32}$ Urbis, above n $3,18$.

${ }^{33}$ Ibid.

${ }^{34}$ My thanks to the Law Society of NSW for providing me with this data in relation to gender distribution in RRR areas of NSW.

${ }^{35}$ Urbis, above n 3, 8-9; Hutchinson and Skousgaard, above n 3, 46.

${ }^{36}$ Urbis, above n 3, 8; Hutchinson and Skousgaard, above n 3, 47.

${ }^{37}$ Law Society of New South Wales, above n 1, 12.

${ }^{38}$ Urbis, above n 3, 23.

${ }^{39}$ Hutchinson, above n 4, 5 .
} 


\section{B Discrimination}

\section{$1 \quad$ Family Responsibilities}

In its 1999 report, Taking up the Challenge - Women in the Legal Profession, ${ }^{40}$ the Victorian Women Lawyers Association highlighted some 16 reports or studies that had been conducted across Australia in relation to the status and position of women in the Australian legal profession. The report concluded that, amongst other things, female lawyers overwhelmingly bore the burden of carer responsibilities and that their carer responsibilities or, indeed, the expectation that they would have children, has 'profound effects' on their careers. ${ }^{41}$ It also highlighted the importance of ensuring that alternative and flexible workplace policy and practices be designed and implemented so as not to cause further marginalisation of those with carer responsibilities. $^{42}$

The private sector in particular has been the focus of criticism for failing to adequately confront the need for meaningful flexible work arrangements. ${ }^{43}$ This failure is arguably part of the picture of women's retreat from the private sector to the government, community and corporate sectors. It is said to reflect (at least in part) women's desire for greater work/life balance and the demand for more meaningful, flexible working arrangements ${ }^{44}$ in order to manage family responsibilities. A Victorian study into flexible work practices found that the most common forms of flexible arrangements available in large firms are part time work ( 36 per cent) and paid parental leave ( 15 per cent), while small firms are more likely to offer flexible holiday rosters (34 per cent) and the ability to work from home (20 per cent), as well as the option of part time work (15 per cent). Government positions tend to offer flexi-time (15 per cent), time-in-lieu (15 per cent) and paid leave to care for sick dependants (12 per cent), and corporate practice most commonly offered paid leave to care for sick dependants ( 15 per cent), flexi-time (14 per cent), part-

\footnotetext{
${ }^{40}$ Trifiletti, above $\mathrm{n} 5$.

${ }^{41}$ Ibid 19.

42 Ibid.

${ }^{43}$ Law Society of New South Wales, above n 1, 10-11.

${ }^{44}$ Kate Eastman, 'Sex Discrimination in the Legal Profession' (2004) 7 University of New South Wales Law Journal 866, 872. Referring to NSW research compiled by consulting firm Keys Young, Eastman notes that the nature of the work and desire to effect reform were considered major factors in women's greater concentration in the community and government sectors but also the greater flexibility of work conditions and practices offered in government, academic and community sectors especially for women with children and family commitments; Neal, above n 4, 6.2 .
} 
time work (43 per cent) and telecommuting ( 30 per cent). Given that the availability of part-time work alone is not enough to retain women in the private sector ${ }^{45}$ it is not surprising that the trend away from the private sector is predicted to continue. ${ }^{46}$

Women who return to work part-time are viewed as being less committed to the firm than the full-time worker. A Victorian study found that 74 per cent of women in fact return to work when their child is around 6 months old. However, most employers believe that they will not return, while partners and managers assume less ambition in those using flexible work practices. ${ }^{47}$ It is also the case that work in the legal profession involves longer hours than the Australian Bureau of Statistics (ABS) average and this has been found to entrench systemic disadvantage for women by creating a 'mummy track'. ${ }^{48}$ This arises because those with carer responsibilities are forced away from long hours. This can lock them into lower status jobs which give more opportunity for flexible work. ${ }^{49}$ The 'mummy track' is characterised by more limited work opportunities, particularly in terms of the nature of the work undertaken. In another Victorian study it was found that 74 per cent of lawyers using flexible work practices 'perceived that the type or quality of work changed after they started working flexibly', while co-workers observed that 'the nature of work given was of lower value than [that given to] full-time employees'. ${ }^{50}$ Women utilising flexible work practices are often assigned background or support roles where the work involves files with 'less profile, less client contact and reduced opportunities to develop legal skills and a client base' - hence the notion of 'pink files' and 'blue files'. ${ }^{51}$ It is widely

\footnotetext{
${ }^{45}$ Law Society of New South Wales, above n 1, 11 .

${ }^{46}$ Urbis Keys Young, The Solicitors of New South Wales in 2015 (2004) The Law Society of New South Wales, $12<\mathrm{http} / /$ lawsociety.com.au/idc/groups/public/documents/ internetcontent/025942.pdf>. Urbis Keys Young estimate that, by 2015, the gender breakdown in private practice will be 52.3 per cent male and 47.7 per cent female. In the corporate sector it is estimated that the split will be 39.5 per cent male and 60.5 per cent female, among government solicitors 36.0 per cent will be male and 64.0 per cent female.

${ }^{47}$ Victorian Women Lawyers, above n 19.

${ }^{48}$ Felice Schwartz, 'Women and the New Facts of Life' (1989) 67(1) Harvard Business Review $65,67$.

${ }^{49}$ Law Society of New South Wales, above n 1, 9; Neal, above n 4, 5.18.

${ }^{50}$ Victorian Women Lawyers, Do You Manage? A Guide to Managing Lawyers with Flexible Work Arrangements (November 2010), $11<$ www.vwl.asn.au/downloads/do_you_manage_ report.pdf $>$.

${ }^{51}$ Eastman, above n 44, 874.
} 
accepted that adopting flexible work practices does limit career progress and reduces a woman's level of commitment to their organisation. ${ }^{52}$

In terms of leaving employment, there is also some indication that women tend to give precedence to their male partner's (eg spouse's) career commitments over their own. A study undertaken by the Law Institute of Victoria, in which a group of women lawyers were surveyed about their reasons for resignation, found that women were almost four times as likely as men to leave practice to accommodate their partner's career commitments. ${ }^{53}$ A 2009 Law Council of Australia report also found that women practitioners were most likely to leave their position in rural practice because of their partner's relocation or for 'family reasons'. 54 This suggests a greater level of mobility for women than for men.

\section{Pay Inequity}

There continues to be substantial disparity between male and female earnings in the private profession, with men earning higher incomes than women overall at both the lower and higher end of the pay spectrum. ${ }^{55}$ When measured on the basis of full-time private work and years since admission, this shows that male incomes are still consistently higher than female incomes. ${ }^{56}$ For example, a male solicitor who had been admitted for less than one year had a mean income of $\$ 62100$ in 2010 while a woman's mean income was $\$ 57100$ in 2010 . The disparity was sharpest for those admitted between 1 and 5 years. For these practitioners the average income was $\$ 88600$ for males and $\$ 77000$ for females. ${ }^{57}$

\footnotetext{
${ }^{52}$ Eastman above n 44, 875; Kaufmann and Frost, above n 19, 8.

${ }^{53}$ Law Council of Australia, 2010: A Discussion Paper - Challenges for the Legal Profession (September 2001), $136<\mathrm{http} / /$ www.lawcouncil.asn.au/library/publications.cfm?fms_folder_ uuid=FBD2A8C8-1C23-CACD-221E-F29AB957FF4D\#2001>.

${ }^{54}$ Law Council of Australia and Law Institute of Victoria, Report into the Rural, Regional and Remote Areas Lawyers Survey (2009), $42<\mathrm{http}$ //www.lawcouncil.asn.au/programs/nationalpolicy/recruitment_retention/rrr.cfm>.

${ }^{55}$ Urbis, above $\mathrm{n} 3,37$ (25 per cent of women reported an income of $\$ 50000$ or less compared with only 19.3 per cent of men. At the higher end of the income scale there was also significant disparity: 43.4 per cent of men reported income in excess of $\$ 100000$ while only 25.6 per cent of women did so); Hutchinson and Skousgaard, above n 3, 48.

${ }^{56}$ Urbis, above n 3, 39.

${ }^{57}$ Ibid.
} 


\section{$3 \quad$ Harassment and Discrimination}

Surveys and research undertaken in NSW, Queensland and Victoria all show that women lawyers are far more likely to report having experienced discrimination - most commonly gender-based discrimination. The 2000/2001 NSW Practising Certificate Survey found that almost a quarter of female respondents reported having experienced harassment or discrimination on the basis of their gender, compared to 3 per cent of male respondents. ${ }^{58}$ The 2002 Remuneration and Work Condition Survey found that women were more likely than men to report experiencing bullying, harassment and discrimination. ${ }^{59}$ In Queensland, a 2003 Membership Survey also found that some 92.3 per cent of those reporting discrimination on the basis of gender were women ${ }^{60}$ while Neal's research reaffirmed that discriminatory practices in Queensland affected women disproportionately. ${ }^{61}$

There has been no study to date with a specific focus on the experiences of discrimination against female lawyers in RRR communities. However, Neal's research into the extent of the prejudice and gender bias experienced by Queensland solicitors more generally suggests that women in RRR practice experience many of the same issues as their city and metropolitan counterparts. ${ }^{62}$

\section{Significance for RRR Practice and Communities}

The research and scholarship highlighted above raises several issues for the future of legal practice and access to justice in RRR areas. First, why is it that female lawyers are under-represented in rural, regional and remote (RRR) legal practice compared to male lawyers, and are more highly concentrated in city and metropolitan areas in terms of their overall presence within the profession? Second, why is there a more pronounced move away from the private sector in RRR areas? Third, how might we interpret the higher rates of sole practitioner participation by female lawyers in RRR practice?

\footnotetext{
${ }^{58}$ Law Society of New South Wales, above n 1, 14.

${ }^{59}$ Ibid.

${ }^{60}$ Hutchinson, above n 4, 33 .

${ }^{61}$ Neal, above n 4, 7.9.

${ }^{62}$ Ibid. Neal surveyed 206 respondents, 81 of whom were from 'rural/regional' areas of Queensland about their motivations to enter and leave the legal profession, their experiences of discrimination and flexible work practices along with barriers to success in the profession. The 'rural/regional' group comprised 34 female and 47 male respondents. Following the survey, Neal conducted 36 follow-up interviews 14 of which were from 'rural/regional' areas comprising 10 female and 4 male participants.
} 
The question of female lawyers' relative absence from RRR practice is important for at least two key reasons: First, a significant body of feminist work suggests that women bring a distinctive and qualitative difference to the practice of law. ${ }^{63}$ On a more pragmatic level, however, it has been projected, in NSW at least, that women will soon outnumber men in the profession. ${ }^{64}$ For this reason it is possible that we could see a sharper decline in the numbers of solicitors willing to work in RRR areas than we have previously seen. The recent Senate Inquiry into Access to Justice (2009) confirms that, already, the lack of legal practitioners willing to work in RRR areas is a 'fundamental problem', ${ }^{65}$ and, given the important role that lawyers play in RRR areas in carrying out a large amount of legal aid work - more than their city counterparts ${ }^{66}$ - and undertaking significant pro bono and voluntary work within their communities, ${ }^{67}$ the possibility of a sharp decline should be considered seriously. The decline in private practice is also an important issue given that the private sector is the largest sector in RRR areas ${ }^{68}$ and is predominately comprised of sole or small practices. ${ }^{69}$

To date there has been a dearth of material specifically considering female lawyers' experiences in RRR practice. This arguably reflects an implicit assumption of spatial and gender normativity. On one view, RRR practice offers the opportunity of a very different practice experience for women because of an enhanced lifestyle, improved capacity for work/life balance as well as the ability to achieve partnership more quickly and to balance family

${ }^{63}$ For example, feminist writers who have explored the ideas of Carol Gilligan, In a Different Voice: Psychological Theory and Women's Development (Harvard University Press, 1982) (who argues that women bring a distinctive 'ethic of care') and Carrie Menkel-Meadow, 'The Comparative Sociology of Women Lawyers: The 'Feminization' of the Legal Profession' (1986) 24 Osgoode Hall Law Journal 897 (who suggests that the greater presence of women in the profession will 'reorient' the profession and legal system).

${ }^{64}$ Urbis Keys Young, above n 46, 4.

${ }^{65}$ Senate Legal and Constitutional Affairs References Committee, Parliament of Australia, Access to Justice (2009) 26 [2.104].

${ }^{66}$ Law Council of Australia and Law Institute of Victoria, above n 54, 3. The report also notes that ' $51 \%$ of respondents indicated that their firm accepted legally aided matters. Of those firms the majority $(50 \%)$ dealt with more than 30 cases per year'.

${ }^{67}$ Ibid 16-7. The survey found that more than 64 per cent of respondents indicated that their firm undertakes pro bono work and 71 per cent of respondents undertake other unpaid voluntary work within their area.

${ }^{68}$ For example in NSW as of October 2010, 15.7 per cent of lawyers in private practice, 11.6 per cent of government lawyers and 2.4 per cent of corporate lawyers were located in rural areas: Urbis, above n 3, 17.

${ }^{69}$ Law Society of New South Wales, 'National Competition Policy' (Discussion Paper, March 2002) 38-9. 
responsibilities more easily ${ }^{70}$ through the increased flexibility offered in 'country' practice. Other research, however, suggests that improved workplace experiences in 'rural/regional' practice may well be illusory ${ }^{71}$ and that the rural, in fact, may act to compound the gendered experience of law. ${ }^{72}$

The comments of a female lawyer speaking about her experience of rural/regional practice in the Victorian Law Institute Journal in 2002 gives an example of this gendered experience. She states:

With so few female practitioners, it's a little bit difficult when you don't see any legal role models on how to operate as a female practitioner. I always thought it would be much easier for a bloke to fit into practice in Bendigo, especially if he played footy.

It may be perceived that it's more difficult for women to practise in the country but that's certainly not been my experience. I pride myself on being able to fit into the established social practices of the male lawyers.

You will find it a lot easier if you can go and have a few beers down at the pub with the boys.

[I] had always regarded [myself] as a solicitor first and a woman second. I was in partnership with two men [in Geelong]. I didn't feel I was a woman. I was a solicitor. It was a partnership and we all had our strengths and weaknesses. $^{73}$

These comments - perhaps unwittingly - expose several layers of gendered 'othering' in the context of rural practice. First, they arguably affirm Thornton's thesis that the practices of male lawyers are (whether consciously or unconsciously adopted) the benchmark norm and women are expected to adopt the norm. It also highlights the ways in which women are expected to

${ }^{70}$ Brown, above n 31, 18; John Teerds, 'Regional, Rural and Remote: Profiles of Practice Beyond the City Limits' (2009) 29(8) Proctor 19, 21. This is also supported by anecdotal evidence drawn directly from my discussions with female practitioners in RRR areas.

${ }^{71}$ Neal, above $\mathrm{n} 4,7.7$.

${ }^{72}$ Research into factors that affect the recruitment and retention of female GPs in rural and remote communities found that 'the difficulties of practising in the country and of being a woman compound each other'. In particular it found that female GPs were more likely to experience 'role conflict' because female medical practitioners commonly assume the primary responsibility for childrearing and the home whether or not they have full-time careers and these commitments conflicted with the longer hours and greater levels of afterhours work undertaken by rural GPs compared to urban doctors: Helen Tolhurst, Jane Malbot and Louise Baker, 'Women in Rural General Practice: Conflict and Compromise' (2000) 173 Medical Journal of Australia 119-20.

${ }^{73}$ Brown, above $\mathrm{n} 31,18$. 
negotiate contradictory gender 'performances'. On the one hand there is an expectation that the woman will perform the role of 'woman' but at the same time that she will disavow her womanness in order to fit in. In essence, this requires integration through the relinquishing of her gender. The narrative also may support Campbell and Leyshon's ideas (explored later) about the importance of alcohol and cultures of drinking to masculine identity and their embeddedness in rural community life. ${ }^{74}$

Anecdotal evidence also suggests that women lawyers simply are '... not attracted to country living' or else have family commitments that keep them in the city. ${ }^{75}$ Whether, and to what extent, family commitments keep women from choosing to practise, or remain, in a RRR area is not known but anecdotally it is considered by some to be a central issue. What is the extent of these differences between city/metropolitan and RRR practice and does it provide a more positive practice experience? Are women in RRR practice increasingly seeing the option of sole practice as a way to better manage their family responsibilities or as a vehicle for achieving greater work/life balance and/or satisfaction? These are important issues, some of which are explored in this article through the case studies; others can only be flagged as issues for future research and exploration.

It is also important to acknowledge recent positive recruitment initiatives such as those developed by the Law Council of Australia, including a campaign to highlight the career benefits for lawyers moving to RRR practice, and the establishment of an interactive website. ${ }^{76}$ However, I argue that gender issues really need to be considered in addition to, or within, these broader strategies.

\section{Gender AND ‘Rural’ Social Space}

Having explored some of the key research and data that considers the status and experience of women (including those in RRR areas) in the Australian legal profession, I now canvass some broad perspectives from feminist and social geographical literature in relation to cultural constructions of gender in rural space. There are various ways of understanding 'rural' space. We

\footnotetext{
${ }^{74}$ Michael Leyshon, 'No Place for a Girl: Rural Youth Pubs and the Performance of Masculinity' in Jo Little and Carol Morris (eds), Critical Studies in Rural Gender Issues (Ashgate, 2005) 104, 106-8.

${ }^{75}$ Justice P W Young, 'Lawyers in country areas' (2002) 76 Australian Law Journal 84.

${ }^{76}$ Law Council of Australia and Law Institute of Victoria, above n 54. The Law Council of Australia launched its Rural, Regional and Remote Law (RRRLaw) initiative during Law Week in May 2011: <http://rrrlaw.com.au>.
} 
usually, and most straightforwardly, define rural space as an 'objectively measurable ... physical space demarcated through ...' pragmatic indicators such as population density, levels of remoteness, accessibility to services ${ }^{77}$ and economic activities. ${ }^{78}$ While socio-demographic characteristics such as these have been shown to be important attraction and retention factors in RRR areas, ${ }^{79}$ it is well recognised that rural, regional and remote areas are not merely physical spaces but are social spaces as well. ${ }^{80}$ As Mormont suggests, 'rurality is not a thing or a territorial unit, but derives from the social production of meaning, ${ }^{81}$ Thus, there is no one single rural space; instead there is a multiplicity of social spaces which overlap the same geographical $\operatorname{area}^{82}$ and which shift subtly over time. ${ }^{83}$

Social identities exist primarily in relation to this socially constructed space because 'it is by the practical apprehension of a structured space that the individual first becomes aware of the world and learns to define his or her position within it'. ${ }^{84}$ Thus, questions of marginality or 'otherness' are directly connected with constructions of the rural; people are othered 'as their

\footnotetext{
${ }^{77}$ In Australia there are three main ways of classifying 'degrees of rurality'. These are: the Rural Remote and Metropolitan Area System of Classification (RRMA); Australian Standard Geographical Classification System (ASGC) and the Accessibility/Remoteness Index of Australia (ARIA). The ASGC, for example, is based upon the distance by road from any given point to the nearest $\mathrm{ABS}$ and assigns one of five population size classes, namely 'Major Cities', 'Inner Regional', 'Outer Regional', 'Remote Centres' and 'Very Remote Centres'. Thus population size is used as a 'proxy for the availability of a range of services in a given area': from Institute for Regional and Rural Research, 'Defining to Focus on "Rural" and "Regional" Research' (Position Paper No 1, University of Ballarat, 2004) 2; Gorman-Murray, Darian-Smith and Gibson, above n 10, 44.

${ }^{78}$ Gorman-Murray Darian-Smith and Gibson, above n 10, 38.

${ }^{79}$ See Trish Mundy, Recruitment and Retention of Lawyers in Rural, Regional and Remote NSW: A Literary Review (2008) Northern Rivers Community Legal Centre $<$ http://www.nrclc.org.au/SiteMedia/w3svc728/Uploads/Documents/RecruitmentRetentionOf Lawyers.pdf $>$ in which issues related to lifestyle accessibility, availability of services and social opportunities are discussed in relation recruitment and retention.

80 Alexandra Neame and Melanie Heenan, 'Responding to Sexual Assault in Rural Communities' (June 2004) Australian Centre for the Study of Sexual Assault, 5 $<$ www.aifs.gov.au/acssa/pubs/briefing/b3pdf/acssa_brief3_intro.pdf $>$.

${ }^{81}$ Marc Mormont, 'Who is Rural? Or How to Be Rural: Towards a Sociology of the Rural' in Terry Marsden, Philip Lowe and Sarah Whatmore (eds), Rural Restructuring: Global Processes and Their Responses (Fulton, 1990) 21, 36.

${ }^{82}$ Jo Little and Patricia Austin, 'Women and the Rural Idyll' (1996) 12 Journal of Rural Studies $101,102$.

${ }^{83}$ Ibid.

${ }^{84}$ Mormont, above n 81, 28. See also Pruitt, above n 8, 359 .
} 
particular socio-cultural identities (or parts of those identities) fail to conform to assumptions and beliefs about the nature of rural society'. ${ }^{85}$

While it is important to recognise the complex and diverse nature of rural spaces in terms of their environments, economies and populations, ${ }^{86}$ as well as the complex nature of rural identities, ${ }^{87}$ it is the case that a number of broad socio-cultural differences have been identified between 'rural' and 'city' culture more generally. These differences are said to both reflect and reiterate the social and cultural construction of societal expectations of men and women. ${ }^{88}$ They also reflect the more acute public/private divide that pervades life in rural places, with the result that 'rural patriarchy tends to be private patriarchy'. ${ }^{89}$ Some of these differences include: more conservative and traditional gender roles, the role of 'rural masculinities', and reduced anonymity and privacy. Each of these is discussed below.

\section{A More Conservative and Traditional Gender Roles}

Elizabeth Teather writes that, in the debate about 'what is rural', there exists a psychological divide between urban and rural Australia, with the persistence of a 'rural mindset' or 'country-mindedness'. 90 This rural mindset, she suggests, is one marked by the 'intransigence of gender relations [in which] most rural men stubbornly cling to patriarchal attitudes and expectations'. ${ }^{91}$ Much rural feminist scholarship has highlighted the male domination of rural institutions and the exclusion of women from decision-making and rural leadership positions, ${ }^{92}$ the presence of more traditional gender roles and the continuing expectation that rural women will devote themselves to family and

\footnotetext{
${ }^{85}$ Jo Little, 'Otherness, Representation and the Cultural Construction of Rurality' (1999) 23 Progress in Human Geography 437, 439.

${ }^{86}$ Gorman-Murray, Darian-Smith and Gibson, above n 10, 37.

${ }^{87}$ Little, above $\mathrm{n} 85,438$ notes that many 'ways and degrees in which people may be 'othered' due to a whole range of personal, spatial and temporal characteristics.' See also Alston, above n 9, 140 in which she states that gender constructions/identities are 'not static or ahistorical, but responsive to changes wrought, for example, through rural restricting and globalisation...'

${ }^{88}$ Alston, above n 9, 140.

${ }^{89}$ Pruitt, above n 8, 366.

${ }^{90}$ Elizabeth Teather, 'The Double Bind: Being Female and Being Rural: A Comparative Study of Australia, New Zealand and Canada' (1998) 8 Rural Society 209, 209-10.

${ }^{91}$ Ibid 215.

92 Ibid; Pini, above n 11; Alston, above n 9, 139; Barbara Pini, 'A Critique of "New" Rural Local Governance: The Case of Gender in a Rural Australian Setting' (2006) 22 Journal of Rural Studies 396, 401.
} 
community, despite considerable changes in their educational and other opportunities. ${ }^{93}$

Research has revealed distinctive differences between rural and city culture, including 'greater social and political conservatism in the country ${ }^{94}$ stronger enforcement of gender rules and traditional roles in the family, ${ }^{95}$ a mythology of mateship among men, and reinforced patterns of female subservience ${ }^{96}$ as well as 'stronger social controls operating through informal and intimate processes and mechanisms'. ${ }^{97}$

Smaller, agriculturally-based rural communities particularly experience a 'resilience of gendered arrangements', ${ }^{98}$ perpetuated in part through the continuing practice of patrilineal farm inheritance, which contributes to men's control of much of the economic wealth in these communities. ${ }^{99}$ The significant loss of services in rural communities, particularly medical and health services, has also had a significant gendered impact. Policies of rationalisation, regionalisation and centralisation have also arguably had a differential impact on women who, in the great majority of cases, are the carers $^{100}$ and volunteers ${ }^{101}$ left to fill the gaps created by the loss of these services. There is also a significant lack of child-care facilities in rural communities, and many commentators note that the burden of family and child care responsibilities rests with women in rural communities. ${ }^{102}$

\footnotetext{
${ }^{93}$ Teather, above $\mathrm{n} 90,215$.

${ }^{94}$ S Kelly, 'City Folk, Country Folk: Demographic and Attitudinal Urban-Rural Differences' (1989) 24 Family Matters 43, cited in Neame and Heenan, above n 80, 5; Julia Watkins and Dennis Watkins, Social Policy and the Rural Setting (Springer, 1984), cited in Neame and Heenan, above $\mathrm{n} 80,5$.

95 Women's Services Network (WESNET), Domestic Violence in Regional Australia: A Literature Review (Department of Transport \& Regional Services, Partnerships Against Domestic Violence, 2000), cited in Neame and Heenan, above n 80, 5; Kenneth Dempsey, $A$ Man's Town: Inequality Between Women and Men in Rural Australia (Oxford University Press, 1992) cited in Neame and Keenan, above n 80, 5.

${ }^{96}$ Diane Gibson, Janeen Baxter and Coralie Kingston, 'Beyond the Dichotomy: The Paid and Unpaid of Rural Women' in Margaret Alston (ed), Rural Women (Centre for Rural Welfare Research, 1990) 11, 24.

${ }^{97}$ Michael O'Connor and David Gray, Crime in a Rural Community (Federation Press, 1989) 25, cited in Neame and Heenan above n 80, 5 .

${ }^{98}$ Alston, above n 9, 140.

${ }^{99}$ Ibid 145-6.

${ }^{100}$ Ibid 148.

${ }^{101}$ Ibid 149.

102 Ibid 139.
} 
There has been a disproportionate loss of young women from rural areas because of inadequate employment options, the need to access higher education and, as Alston finds, 'to escape the masculine culture [which is] evident in the sporting profile, power structures and employment opportunities that restrict their choices' ${ }^{103}$ Aside from fewer employment opportunities for women, there are distinctly gendered divisions of labour in rural Australian communities, with males dominating agriculture, professional roles and local government. Women are more likely to be situated in lower status positions such as nursing, administration and customer service, and more likely to be engaged in the casual workforce. ${ }^{104}$

Cloke and Milbourne add a further dimension to the inter-relationship between discourses of gender and rurality. They highlight complex national, regional and localised constructions of rurality and suggest that within any particular rural space there will exist 'cultural constructs of rurality which combine different scales of received and circulated meanings, 105 and that such constructions will invariably shape our understanding of gender. In other words, the rural can be 'embodied through both women and men on different scales, producing stereotypes of the ideal country man or woman'. ${ }^{106}$

A national construction of the meaning of rurality is perhaps the most recognisable. Arguably, many people have a particular idyllic vision of rural life: a vision of a 'problem-free, hidden world of peace, tranquility, close-knit community and proximity to the natural'. ${ }^{107}$ A national construction of rurality is given greater force in Australian culture by the romantic and enduring ideas Australians hold about the nature of rural life and the role of 'the bush' as the imagined seat of the national identify. ${ }^{108}$ This traditional rural imagery is said to reflect a more pronounced sense of importance on home and family; in this imagery attitudes to women's place remain highly patriarchal and the rural is built on particular interpretations of masculinity and femininity that see women 'representing the innocence of the natural world' which 'active masculinity must support, protect and oversee'. ${ }^{109}$ Little and Austin also argue that the idyllic vision of rural life or the 'rural idyll' 110

\footnotetext{
${ }^{103}$ Ibid 150.

${ }^{104}$ Ibid 153.

${ }^{105}$ Cloke and Milbourne, above n 10, 361.

${ }^{106}$ Gorman-Murray, Darian-Smith and Gibson, above n 10, 47.

${ }^{107}$ Cloke and Milbourne, above n 10, 361.

${ }^{108}$ Kay Schaffer, Women in the Bush: Forces of Desire in the Australian Cultural Tradition (Cambridge University Press, 1998).

${ }^{109}$ Little and Austin, above n 82, 103.

${ }^{110}$ Ibid 102.
} 
helps shape and sustain patriarchal gender relations and that it incorporates, both consciously and unconsciously', strong expectations about gender roles and thus impacts on the nature of women's experience within the rural community. ${ }^{111}$

A regional construction of the rural, on the other hand, is said to represent the 'spatial organisation of particular capitalist processes', avenues of cultural identity and sites for social interaction, ${ }^{112}$ while localised constructions of rurality reflect the many and varied local patterns, identities and beliefs which will be particularly influenced by individualistic factors such as class, gender, ethnicity and are therefore likely to be the most complex and multilayered. ${ }^{113}$

\section{B Rural Masculinities}

A growing body of literature has developed around the role of rural masculinities in understanding the place of gender in rural space. As Barbara Pini notes, it reflects a 'shifting paradigm ... away from an investigation of women's disadvantage to the ... question of men's advantage and the actions, practices and discourses by which men seek to retain this advantage'. ${ }^{114}$ Conceptually, masculinity is 'typically viewed as socially and culturally constructed and related to power'. 115

Moving away from 'simplistic' and 'static' ${ }^{116}$ sex-role/socialisation theory, Carrigan, Connel and Lee introduced the notion of 'hegemonic masculinity'. ${ }^{117}$ Hegemonic masculinity is a "particular variety of masculinity that is culturally exalted compared with other subordinated masculinities...'; it is a 'dominant discourse' whereby 'some men come to legitimate their power over some other men and over women'. ${ }^{118}$ Importantly, it may not necessarily be the most common form of masculinity and it is subject to change in that different masculinities are hegemonic depending on the time, place and context. ${ }^{119}$

\footnotetext{
${ }^{111}$ Ibid.

${ }^{112}$ Cloke and Milbourne, above n 10, 362.

${ }^{113}$ Ibid 364.

${ }^{114}$ Pini, above $n 11,1$.

${ }^{115}$ Ibid 10.

116 Ibid.

117 Tim Carrigan, Bob Connell and John Lee, 'Towards a New Sociology of Masculinity' (1985) 14 Theory and Society 551, 579.

${ }^{118}$ Pini, above $\mathrm{n} 11,10$.

${ }^{119}$ Ibid 11.
} 
The notion of hegemonic masculinities has been the subject of criticism. ${ }^{120}$ Among other things, it is said that it has been over-simplified and has 'come to be used as shorthand to refer to a categorical set of traits and behaviours' and typically portrayed as negative. ${ }^{121}$ These criticisms highlight the need to ensure that the concepts of masculinities are understood as 'multiple and as hierarchical' and as representing the 'nuanced and contested nature of gendered power as it manifests between different groups of men and women'. ${ }^{122}$

Hugh Campbell and Michael Bell draw a useful distinction between 'the masculine in the rural' and 'the rural in the masculine'. The 'masculine in the rural' refers to the 'various ways in which masculinity is constructed within rural spaces and sites'. ${ }^{123}$ The 'rural in the masculine' refers to the 'way in which notions of rurality help to constitute notions of masculinity' more generally.

\section{1 'Masculine in the Rural'}

Alston argues that, in rural areas, hegemonic masculinity is evident in the institutional structures through which gender relations are constructed and reconstructed in everyday life and which allow 'not only male power and influence to be super-ordinate', but also to be '... normalised and projected onto ...' women as natural. ${ }^{124}$ She also suggests tacit support of hegemonic masculinity by women in rural communities. ${ }^{125}$ While some suggest that there are fewer sites for patriarchal dominance in rural communities today, Alston argues that hegemonic masculinity 'still dominates and constrains gender negotiations'. ${ }^{126}$

A particularly strong discourse of hegemonic masculinity in rural space concerns ideas about 'the farmer'. Many inland rural communities remain agriculturally based and, given that farming and agriculture in Australia

\footnotetext{
${ }^{120}$ See a useful summary of some of these criticisms in Pini, above n 11, 13.

${ }^{121}$ Ibid.

${ }^{122}$ Ibid.

${ }^{123}$ Hugh Campbell and Michael Bell, 'The Question of Rural Masculinities' (2000) 45 Rural Sociology 532, 540.

${ }^{124}$ Alston, above n 9, 141.

${ }^{125}$ Ibid 143.

${ }^{126}$ Ibid.
} 
continue to exist as a 'strongly gendered industry', 127 one of the main representations or constructions of the rural has been a focus on masculinities in farming and agriculture (where male dominance over land and environment are central) and which rest heavily on stereotypical masculine attributes. ${ }^{128}$ Liepins highlights 'two narratives of masculinity' which emerge from this analysis, namely 'tough men' and 'powerful leaders'. Conversely, dominant discourses of femininity in the context of agriculture are based on their nurturing and helping roles. ${ }^{129}$

The rural has also been explored as the site for the performance of a particular stereotypical form of traditional masculine gender identity. In particular, Campbell examines masculinity in a rural New Zealand pub, suggesting that it is marked by 'conversational cockfighting and disciplines of drinking', during which 'hierarchies of knowledge, historical embeddedness, and legitimacy [are] established'. ${ }^{130}$ These combine to ensure that a particular version of masculinity reproduces itself. Leyshon also notes the importance of alcohol and cultures of drinking to masculine identity" ${ }^{131}$ and observes that 'country pubs are embedded in idyllic versions of rurality which position it [the pub] at the centre of rural community life'. ${ }^{132}$

The ways in which women are represented in rural media have also been found to reinforce hegemonic masculinity. In particular, Liepins notes that the cultural and editorial processes of media and farming organisations work to 'normalise and legitimise' certain masculinities ${ }^{133}$ while Alston identifies the role of media, church and the market in the 'active reconstitution of gender relations in everyday life'. ${ }^{134}$

\section{2 'Rural in the Masculine'}

The term 'rural in the masculine' refers to the way in which our ideas or beliefs about rurality help to constitute ideas of masculinity in broader

\footnotetext{
${ }^{127}$ Ruth Liepins, 'Making Men: The Construction and Representation of Agriculture-Based Masculinities in Australia and New Zealand' (2000) 65 Rural Sociology 605, 609; Alston, above $\mathrm{n} 9,139$.

${ }^{128}$ Little, above $\mathrm{n} 8,665$.

${ }^{129}$ Liepins, above n 127, 613.

${ }^{130}$ Hugh Campbell, 'The Glass Phallus: Pub(lic) Masculinity and Drinking in Rural New Zealand (2000) 65 Rural Sociology 562, 570.

${ }^{131}$ Leyshon, above $\mathrm{n} 74,105$.

${ }^{132}$ Ibid 107.

${ }^{133}$ Liepins, above $\mathrm{n}$ 127, 613.

${ }^{134}$ Alston, above n 9, 141.
} 
community consciousness. The notion is concerned with questions of 'real and imagined qualities of the rural ${ }^{135}$ and so may have particular relevance to how rural is understood and perceived by those in both urban and rural spaces. ${ }^{136}$ The earlier discussion on the national construction of rurality is particularly relevant to this question. Pini notes that 'images of rurality and agriculture remain dominant in the Australian consciousness' and colour the perception of manhood - the 'man on the land'. ${ }^{137}$ Feminist writers have highlighted the marginal figure of women in this landscape, who are seen 'more as supporters of men and admirers of masculinity than for their own sake'. Pini writes that '[c]onventional discourses of rurality and masculinity continue to enjoy privileged status in many cultural representation of the Australian nation, ${ }^{138}$ and Schaffer writes that they help to determine Australian identity. ${ }^{139}$ This marginality or secondary role to which women have been assigned in this masculine image of the rural poses interesting questions as to how these might impact on recruitment and retention in RRR areas.

\section{Reduced Anonymity and Privacy}

It is widely acknowledged that rural community life carries reduced anonymity and privacy. Rural professionals, such as nurses, ${ }^{140}$ doctors $^{141}$ and social workers, ${ }^{142}$ report facing high levels of visibility which have the effect of blurring professional and personal boundaries'. ${ }^{143}$ High visibility and, thus, the lack of anonymity and privacy, can have both positive and negative aspects. It has been noted that lawyers in a smaller town are often much more high-profile than those in a larger one and face considerable community expectations about their role which can impinge on their personal life. ${ }^{144}$

\footnotetext{
${ }^{135}$ Campbell and Bell, above n 123, 542.

${ }^{136}$ Pini, above n 11,18 .

${ }^{137}$ Ibid 21.

${ }^{138}$ Ibid.

${ }^{139}$ Schaffer, above n 108, 1 .

${ }^{140}$ Candice Roberge, 'Who Stays in Rural Nursing Practice? An International Review of the Literature on the Factors Influencing Rural Nurse Retention' (2009) 9(1) Online Journal of Rural Nursing and Health Care 82, 84.

${ }^{141}$ Richard Hays et al, 'Why Doctors Leave Rural Practice' (1997) 5 Australian Journal of Rural Health 198, 200.

${ }^{142}$ Rosemary Green, Raeleene Gregory and Robyn Mason, 'It's No Picnic, Personal and Family Safety for Rural Social Workers' (2003) 56 Australian Social Work 94, 95-6.

${ }^{143}$ Ibid.

${ }^{144}$ Jeff Giddings, Barbara Hook and Jennifer Nielsen, 'Legal Services in Rural Communities: Issues for Clients and Lawyers' (2001) 26 Alternative Law Journal 57, 60.
} 
Others cite this 'closeness' of rural life as the very reason for choosing to move to and remain in a country area. For these lawyers, the country is where a real sense of community connection is possible, ${ }^{145}$ including closer and more trusting relationships with clients. ${ }^{146}$

Others have noted the greater levels of surveillance in rural space, particularly of women and girls. ${ }^{147}$ In their research concerning young women's sexuality in rural space, Hillier and Harrison report that young women in particular felt under constant surveillance by others living in their community and that their perceptions of surveillance were much stronger than those of young men. ${ }^{148}$ They write: '[O]ne of the most pervasive characteristics of life in a small town is the lack of privacy. In the case of young women for example, when age and gender are added to the mix, their private lives are rendered even more knowable'. ${ }^{149}$

\section{iV CAse Studies}

Two case study interviews were conducted as part of the preliminary stages of a broader phenomenological research study into the lived experiences of female lawyers in RRR areas ${ }^{150}$ and in accordance with guidelines for the ethical conduct of research. ${ }^{151}$ The two female lawyers, Jenny and Lee, ${ }^{152}$ had previously practised in a regional/rural location within Australia but no longer do so. They were invited to share their experiences of: how they came to practise in a RRR area, the most and least satisfying aspect(s) of RRR practice for them, whether they saw any difference(s) for men and women in

${ }^{145}$ Brown, above n 31, 18; Rennie Anderson, 'The Tyranny of Distance ... and Demographics' (2009) Australasian Law Management Journal 14.

${ }^{146}$ Anita Punton, 'Beyond City Limits' (2002) Australasian Law Management Journal 24, 24.

${ }^{147}$ Lynne Hillier and Lyn Harrison, 'The Girls in Our Town: Sex, Love, Relationships and Rural Life' in Linda Briskman, Margaret Lynn and Helen La Nauze (eds), Challenging Rural Practice: Human Services in Australia (Deakin University Press, 1999) 194, 195.

148 Ibid.

${ }^{149}$ Ibid 1.

150 These two interviews were conducted in the context of a broader $\mathrm{PhD}$ research project. These preliminary interviews are clearly not indicative of all women lawyers' experience; indeed, they were never meant to be so. These interviews were designed to 'test the waters', so to speak, and to gain insight into issues faced by female lawyers in RRR areas in order to inform the development of research questions and appropriate methodological approaches. The interviews were recorded and subsequently transcribed and analysed.

151 The research was conducted in accordance with the Ethical Guidelines of Griffith University; Application Reference No: Law/12/09/HREC.

${ }^{152}$ These are not their real names, rather they are pseudonyms used to protect their identity. 
practising in their geographical area, and their reasons for leaving. ${ }^{153}$ Jenny, a mature-aged woman who came to the practice of law later in life, had been a partner for many years in a medium-sized regional firm in Queensland. In contrast, Lee entered regional practice as a young, newly admitted solicitor and began her legal career as an articled clerk in a small community in rural Victoria.

It was very important to me that Jenny and Lee's stories be offered in their own words. Some editing of the text was necessary, principally to protect identity, but I was always mindful to ensure that the overall integrity was not compromised. Their stories will be interpreted through the prisms of 'experience' and the ways in which women's subjectivity is formed and shaped in the context of dominant discourse. In particular, the work of Teresa de Lauretis has been adopted in constructing experience not simply in an individualistic way but rather in a way that emphasises subjectivity as 'an ongoing construction, not a fixed point of departure or arrival from which one then interacts with the world'. ${ }^{154}$ Rather, it is the effect of that interaction. Thus Jenny and Lee's experience is seen as the product of their 'personal, subjective, engagement in the practices, discourses and institutions that lend significance to their ... world' ${ }^{155}$

\section{A What Were Their Motivations for Entering RRR Practice?}

Both Jenny and Lee identified the attraction of lifestyle and community connections as significant factors in their decision to take up a position in the RRR area. Jenny states:

[After completing my articles] I then resigned to have children. The theory was good, the sitting at home was not. I worked in [place] for a little while, until [my child] was six months old I guess and then from there - we were there a couple of years before I moved to [regional town]. It was definitely a green change. It was also a chance to further my career and to stay within Queensland which became a priority at the time.

\footnotetext{
${ }^{153}$ In presenting Jenny and Lee's narrative I decided that the most powerful way of conveying their experience was to allow their words to stand alone with as little interruption to the flow as possible. Consequently, their narrative is delivered with limited introductory comment and simply with headings to signpost its contextual relevance. Analysis of the narratives is conducted separately.

${ }^{154}$ Teresa de Lauretis, Alice Doesn't: Feminism, Semiotics, Cinema (MacMillan, 1984) 159.

${ }^{155}$ Ibid.
} 
Jenny also described the move to regional practice as one that involved decisions about child care responsibilities. The decision was made that her husband would leave his employment and take on the role of primary carer:

And at the same time when we moved to [regional location] my husband [gave away his job and] has, in a technical sense, been a primary care giver ever since and you know not too many female lawyers are lucky enough to have that. And it doesn't matter [who you talk to and] what role they have or how senior they might be, usually that sort of basic running around after school, or whatever else, or the costume for the dance, falls back to the female.

Lee grew up in an outer suburb of Melbourne with some connection to country Victoria through her grandmother who lived there and whom she regularly visited as a child. Lee had no desire to enter rural/regional practice but did so after she was offered an interview for a job and found, somewhat unexpectedly, that she 'fell in love with the town'. She comments:

I never had a desire to live or practise in the country at all. So, initially for me it was not about working in the country. I went for an interview one day in [the rural area] and fell in love with the town. There was a real sense of community. I remember going early before my interview to look around. Immediately across the road from the firm was a park. Before my interview I went and sat in the park and I watched everyone. People were out walking, waving and saying hello to each other; every place I went into was so friendly. I went into a shop and the shopkeeper said 'you're not from around here, what brings you here?' When I told him I was going for a job he said 'you'll love it here'. I left the shop with a business card of someone who could help me with rental accommodation just in case I got the job; it was incredible. I felt so welcomed. By the end of the day I would have been devastated if I didn't get the job.

\section{B What Were the Most Satisfying Aspect(s) of RRR Practice?}

Jenny and Lee were asked to consider what they felt were, for them, the most satisfying aspect(s) of practising in their particular regional/rural location. Jenny identified the immense satisfaction she gained in working for and helping clients. She states:

I am trying to think about what makes it regional because the most satisfying [thing] remains today and I think it's wherever you are... I love being able to help people. One day we had an elderly lady whose husband wasn't well and he'd done everything and taken care of everything their whole lives and she was terrified. It's that. And as I said, that is not 
necessarily a regional thing. Probably helping women in those situations you do see it more regionally... I think that those who are in it for the money or for grandios[ity], that is short-lived because you have got to enjoy what you do. Life's too short.

Lee considered the most satisfying aspects of her rural practice experience related to career/professional opportunities and the social aspects of country lawyering available to her. She says:

There were lots of positives in working in rural/regional practice. For a start I gained far more experience than I would have in the city. From the time that I started I was appearing in the Family Court and allowances were made for me because we were in the country. As an articled clerk I would just be given leave to appear and was even doing pleas. My friends in the city were still on their induction after 4 weeks. Then they'd be photocopying and not really given much responsibility... He was also really supportive... After [completing] my articles there, the day I was admitted he made me an associate of the firm.

Also, it was great when courts were on circuit in [regional area]... This meant that barristers would come to town for 2 weeks while court was sitting and there was a real social element to it which I loved. Every second night you would be having dinner with those barristers and magistrates.

\section{What Were the Least Satisfying Aspect(S) of RRR Practice?}

When asked about what they felt was the least satisfying aspect or aspects of RRR practice, both Jenny and Lee identified issues connected to gender-based discrimination. Jenny spoke about the continued existence of 'the boys club' but considered that this was an issue not just confined to regional practice. She stated:

Again, not necessarily regional... the boys club still exists and in a strong way. As I said I have been fortunate along the way. Whether I chose to ignore it or whether, you know, it just never really mattered to me, sort of it is only in the last few years that I have perhaps seen it working a bit more up close... It is extraordinary. no matter what position you're in, that those, I guess in the technical sense, who are beneath you, who'll go off and, you know, try and work against you and do other things and have the meetings over a beer and then try to undermine you. And that's probably more to do with politics and egos than anything else. But I guess in many ways in different degrees it happens in every level. 
Jenny did note that finding a person who 'fitted' the firm's values and culture can often be difficult in regional practice simply because there are fewer people to choose from. She states:

You are sort of managing the different personalities, being a 'fit' in a firm is an important factor. And that is where managing regionally becomes all the more harder. You've got to be able to get to a point where you [just] don't take anyone on [but] that is sometimes the philosophy of some of them; if there is a new person in town or someone willing to come, well we'll take them. Sometime matters are so extreme it has to be done and they don't have the benefit of picking and choosing but I have seen it come undone and it can be detrimental to a firm...

For Lee, the least satisfying aspects of her rural practice experience related to what she identified as her sense of 'complete visibility' within the community. This made it difficult for her to achieve a sense of work/life separation. She reported that, at the time she began with the firm, she was assigned all of the family law matters because this type of work was seen as 'better suited to a woman'. While she had no desire to undertake family law work, as a newly admitted solicitor she felt she had little choice. She commented:

As a woman working in family law, clients would think it was OK to approach me in the supermarket and, over the frozen peas, ask me questions about their case. I believe that this would never have happened if I were a man. As a woman in family law and as a woman in a rural area, you were always seen as being 'available'...Grocery shopping and having a 'clientfree' weekend became impossible. I got to a point where I couldn't deal with that anymore and I left the practice altogether. I then accepted a job in [a larger regional centre of Victoria]. I felt more comfortable there. I felt that I could live and work there without feeling like I was accosted in the street. But even in [that location] there was always a sense of being 'on show'. At that time I did a lot of criminal law work. You would be at court working with the police and prosecutor, then you would see them around town. I felt under the microscope.

Lee also identified the more limited social opportunities available in the smaller country town when compared to the larger regional centre she moved to. She comments:

I found a real difference between the small country community and larger regional centre. The smaller community offered less social opportunities because there were fewer firms and they were more 'cut throat'. In my town you had three different firms: one was the old established firm, another came from the city and most of their work was connected with the city and the third was the younger more 'hip' firm. They were very competitive with 
each other and so each was often disparaging about the other and there was no socialising really. I found that environment really hard.

\section{Do You See Any Differences for Men and Women in RRR Practice?}

Jenny and Lee were asked whether they saw any difference(s) for men and women in practising in their geographical area. Jenny identified the problem of a lack of professional support networks and absence of female mentors for female lawyers in RRR areas. This was linked to the lower numbers of female lawyers and female professionals generally in an area. She saw this as an especially acute issue for young female lawyers who moved to a RRR area from elsewhere. The fact that they are not from that geographical location means that they are less likely to have an existing support or friendship network within the community, leading to feelings of isolation. Where there were few females in the area, or where the young lawyer was the only female lawyer in her firm, this presented particular challenges. She observed that ultimately these things led to female lawyers leaving. She commented:

Yes, I think that [the level of support] is a part of it....I think that's important [particularly] where they may be the only female in the firm. So you know... yeah, it's not going to provide all the answers but if you have got someone going through the same experiences or have been through those experiences then it may help.

Jenny identified discrimination against female lawyers as being a significant issue that she believes is not being talked about or acknowledged. She expressed concern about the prevalence of more insidious forms of discrimination which are harder to detect and act on:

I never believed that I had any issues with discrimination or the glass ceiling or anything else. Being a little bit older and ... you see it. And my concern ... it is not being spoken about and it's not called what it is, let alone being openly affected but I think that is the danger. If it moves underground, for want of a better term, how do we deal with it? If people are subconsciously - and some of it is, I think - making decisions based on gender, how do you deal with that? It is not easy. I think it is much easier, as unfortunate as it is, to deal with open discrimination.

While Jenny identified the problem of discrimination as one affecting female lawyers regardless of location, RRR practice may present particular challenges for female lawyers because of greater conservatism found in rural practice generally. She comments: 
I think it [a conservative attitude towards women] is no doubt everywhere but I think it is highlighted in RRR because the way I saw it that the larger, older more established firms are still male partners now in their 50s and 60s. They were brought up with mums at home and dad runs the farm. It's how they operate and as much as I said they accept that females are equal, it's really in their blood that they're not. And yeah so, as I said ... it's a generational thing...

Jenny related a personal experience that occurred in the course of her regional practice and that reflects these more conservative ideas about gender roles:

I'm trying not to be critical of them ... I worked with a brilliant team of male partners who would hate to think that they were ever chauvinistic in any way .... and then there was the phone call to say 'we're going fishing on a charter boat for a day, we'll do something with you another day'. It wasn't even 'would you like to come', it's just 'you're not invited'. But on the face of it - some of them might have clicked — but they just didn't see anything wrong with that. I was a bit flabbergasted but just let it slide. They wouldn't have thought twice about what the issues were there. I think that's what's part of it ... there's not enough understanding of what it really means when things like that are said; what message is being sent. So, that's difficult whereas, we [she and her current legal practice partner] were talking about the state of origin and getting ... tickets. He said 'Oh my brother's got some. We'll see how many I can get. Even if it just means you and I going and it was ... I just looked at him ... and he said 'is that alright'? It was a breath of fresh air. That's where I see the differences. With some people not only is being female not an issue, it's not even on his radar.

\section{E Why Did You Leave RRR Practice?}

Jenny and Lee were asked about their decision to leave regional/rural practice. Both identified family and relationship factors as a primary, but not sole, motivator in their decision. For Jenny leaving regional practice and returning to Brisbane was about a combination of family and professional factors. She says:

Yes, it was absolutely for family support. All of my family is still in Brisbane. And, I don't want to sound arrogant, but at the end of the day I felt I had hit the top in [regional area]. There were more opportunities in Brisbane. And opportunities beyond private practice too...

Lee's decision to leave rural/regional practice was made after she formed a relationship and decided to move away to be with her partner. This decision was made much easier by the fact that she had already decided that she no 
longer wanted to work under the difficult circumstances that she had encountered in practice. She states:

I left regional practice and moved to Brisbane after I met my partner who lived there. But I was very clear at that stage that I did not want to work in a regional or rural area again. Even in [the larger regional centre] there was always a sense of being "on show" [and feeling like I was] under the microscope.

\section{F Insights into the Intersections of Gender, 'Rurality' and Law}

While the experiences of Jenny and Lee cannot be seen as indicative of all female lawyers' experiences, they nonetheless offer some insight into the gendered power relations that can exist in the context of RRR practice, particularly for women occupying the position of 'outsider' in rural social space. At a basic level the case studies highlight the increasing phenomenon of the 'tree change' movement and affirm the apparent importance that family and relationship factors play in decisions to leave RRR practice, especially where one's ties are not within the particular community. Jenny and Lee also report significant professional rewards that they gained from their regional/rural practice experience. Lee's comments, in particular, support anecdotal evidence showing that rural/regional practice affords a unique career opportunity as it can provide a breadth of experience, particularly for new graduates, that they would generally not otherwise gain ${ }^{156}$ either in the city or in the context of a larger firm.

While Jenny and Lee report that rural/regional practice was rewarding in many respects, they also faced some particular challenges as a result of the ways in which gender relations were constructed within their particular space. Their stories reveal a sense of oscillation between their gendered invisibility on the one hand and their visibility on the other. It is clear that work in rural communities generally carries higher levels of visibility than does city practice and that rural lawyers can have difficulties in maintaining personal boundaries. However, it may be that female lawyers experience particular gendered consequences. For Lee as a young, single woman and the only female lawyer in the community, her 'complete visibility' was at the forefront of her gendered experience and ultimately led to her exit from rural/regional practice. Jenny's comments about the relative absence of female lawyers and the problem of professional isolation highlights the gendered invisibility in a

\footnotetext{
${ }^{156}$ Brown, above n 31, 16.
} 
physical sense, while her experiences of exclusion and the 'boys club' point to a broader invisibility in the context of gender relations.

Both Jenny and Lee report experiences where they were treated less favourably than males because of their gender. The expectation on Lee to simply take up the firm's family law work because it was 'better suited to a woman' resonates with the gendered assumptions and sexual division of labour noted earlier. ${ }^{157}$ This, along with Jenny's experience of the 'boy's network' and her exclusion from the work fishing trip, suggests that the "homosociability of the metaphysical "club" mentioned by Margaret Thornton is alive and well:

The socially inscribed images of women as handmaidens who assume responsibility for the comfort of others and the well-being of an environment populated by important men, are sustained by norms of homosociability. Sex specific and exclusionary practices assist in constructing women as 'other' within the organisation. Those whose perceived role is to serve can never be admitted to the 'community of equals'... The homosociability of the metaphysical 'club' also shapes the 'private' social life of lawyers in a way that contributes to the power capital of its members. ${ }^{158}$

While, clearly, gendered power relations and expectations are not unique to the rural practice experience, the case studies do affirm the operation of a more conservative gender regime as previously discussed ${ }^{159}$ and suggest that rural space can indeed act to compound the gendered experience of law for women and thereby impact on their attraction to and retention in RRR communities. Further work and research in this area is necessary.

\section{Conclusion}

This article has sought to highlight the relative absence of female lawyers, both within RRR practice generally and within the broader literature more specifically, suggesting an implicit assumption of spatial and gender normativity. There is a need for a research focus on female lawyers in RRR areas in order to further understand how constructions of gender and rurality might impact upon their legal practice experience. The lived experience of

\footnotetext{
${ }^{157}$ See Part II, section A 'Segmentation' for discussion on this point.

${ }^{158}$ Margaret Thornton, “'Liberty, Equality and ?”: Endowing Fraternity with Voice' (1996) 18 Sydney Law Review 553, 564.

${ }^{159}$ See Part III, section A 'More Conservative and Traditional Gender Roles' for discussion on this point.
} 
two female lawyers practising in rural/regional communities in Australia has highlighted the complex nature of the gendered experience of law in rural space. While they reported that rural/regional practice was professionally rewarding in many respects, their narratives suggest that they face some particular challenges in rural areas. These include the challenges of: managing increased levels of visibility and invisibility in rural space, the more pronounced feelings of professional isolation, the sexual division of labour and the effects of a more conservative gender regime which they experience there.

Other narratives also point to an expectation that female lawyers will manage contradictory gender expectations in order to fit in to rural/regional practice. That is, that they will perform the role of 'woman' but at the same time also disavow their womanness in order to fit in. Together, these suggest that rural space can act to compound the gendered experience of law and thereby impact on women's attraction to and retention in RRR practice. 